\title{
Comparative Diets of Rambouillet, Barbado, and Karakul Sheep and Spanish and Angora Goats
}

\author{
L.E. WARREN, D.N. UECKERT, AND J.M SHELTON
}

\begin{abstract}
Diets of Rambouillet, Karakul, and Barbado sheep (Ovis aries) and Spanish and Angora goats (Capra hircus) grazing in 3 plant communities in western Texas were determined by microhistological analysis of fecal samples. Grasses were commonly the major foods of all sheep breeds as well as Angora goats. Forbs were major diet items of all breeds of sheep and goats when they were readily available. Spanish goats, and to a lesser extent Angora goats, relied heavily on browse. Barbado sheep consumed more browse than did Rambouillet or Karakul sheep. Diets of Rambouillet and Karakul sheep overlapped considerably, whereas diets of Rambouillet sheep and Spanish goats were quite dissimilar. Barbado sheep appeared to occupy a food niche intermediate between that of the goats and the other sheep breeds. Spanish and Angora goats exhibited the strongest tendency and Karakul sheep exhibited the least tendency to selectively graze. Neither Barbado nor Karakul sheep consumed sufficient amounts of undesirable shrubs to be considered valuable for brush suppression.
\end{abstract}

Rangeland forage utilization and total meat and fiber production could potentially be enhanced by identifying breeds of sheep or goats with the physical capabilities and diet versatility to better adapt to the currently available forage resource. Goats are generally more efficient at suppressing brush than cattle or sheep since they tend to select a wider variety of plants (Merrill and Taylor 1976). They also have the ability to shift their diet from herbaceous broad-leaved plants to shrubs (Scifres 1980). Goats are hardy and adapted to feed over rugged terrain, and can be combined with sheep and cattle to utilize vegetation which otherwise would be used very little (Campbell et al. 1962). Goats utilize a broader spectrum of plants than sheep, generally exhibit a greater tendency to browse, and therefore more efficiently utilize brush-infested rangeland (Maher 1945; Wilson et al. 1975). However, Malechek and Leinweber (1972) reported that grasses were readily selected by Angora goats during summer and fall on the Edwards Plateau of Texas, even though browse was abundant.

Merrill (1975) reported that Spanish goats completely consumed new growth of vasey shin oak (Quercus pungens var. vaseyana), hackberry (Celtis reticulata) and lime pricklyash (Zanthoxylum fagara), while Angora goats utilized only about $30 \%$ of the shin oak and $80 \%$ of the hackberry and lime pricklyash. The goat's ability to utilize a diverse variety of vegetation is attributed to their dexterity, narrow mouth, mobile upper lips, prehensil tongue, and propensity to stretch upward on the hind legs and employ the agile front legs to utilize browse species (Maher 1945, Staples et al. 1942).

Sheep usually rely on grasses as their major diet component while forbs are selected opportunistically (Ellis et al. 1977, Bryant et al. 1979, MacCracken and Hansen 1981). Van Dyne and Heady

\footnotetext{
Authors are research associate and professors, respectively, Texas Agricultural Experiment Station, 7887 N. Hwy. 87, San Angelo, Texas 76901

This article is approved by the Director. Texas Agricultural Experiment Station as TA-17838

The authors wish to express their appreciation to Mr. Phillip Robbins of Fort Stockton, Texas, for providing land for a portion of this study and to Dr. C.M. Rowell for assistance in identifying plant specimens. This research was funded by the United States Agency for International Development Title XII Small Ruminants Collaborative Research Support Program under Grant No. AID/DSAN/XII-G-0049, in collaboration with Empresa Braisileria de Pesquisa Agro-pecuaria; Brazil.

Manuscript received July 12, 1982.
}

(1965) indicated that a single plant species may frequently compose $50 \%$ or more of a sheep's dietary sample.

Differences in diets of sheep and cattle have been attributed to differences in their ability to be selective (Dudzinski and Arnold 1973). Van Dyne (1968) stated that sheep spend more time selecting a higher quality diet compared to cattle. Studies by Meyer et al. (1957), Arnold (1960), and Wilson (1976) indicated that grazing sheep select a diet of higher nutritional value than the average for available forage. When the availability of green herbage is high, the difference in digestibility between the diet selected by sheep and that of all available herbage is the result of selection for the more digestible fractions, such as preference for leaves over stems (Arnold 1960) and new growth over mature herbage (Hamilton et al. 1973).

Karakul and Barbado sheep are not common on West Texas rangeland, and their diet preferences and utility for suppressing undesirable range plants are not known. Intensive studies are needed to determine the food habits of these exotic breeds in relation to that of sheep and goat breeds currently used. If differences do exist, such information could increase the efficiency of plant resource utilization and brush management, and benefit the economics of the range livestock industry. Therefore, the purpose of this study was to determine if significant interspecific and intraspecific variation in seasonal diets of Rambouillet, Karakul, and Barbado sheep, and Spanish and Angora goats occurred in selected range plant communities in western Texas.

\section{Methods}

\section{Study Areas}

The sheep and goats grazed in common on 3 selected range types: a common curlymesquitegrass-threeawn-liveoak (Hilaria belangeri-Aristida spp-Quercus fusiformis) community, a mixed grass-honey mesquite (Prosopis glandulosa var. glandulosa) community, and a creosotebush-tarbush (Larrea tridentata-Flourensia cernua) community.

The common curlymesquitegrass-threeawn-liveoak community was in an 81-ha pasture on the Frances Hill Ranch, $47 \mathrm{~km}$ southeast of Sonora in Edwards County. The Low Stony Hill range site consisted of gently sloping to rolling hills, with slopes of 1 to $20 \%$. Soils were very shallow, moderately permeable, calcareous, stony clays of the Tarrant series resting on fractured limestone (Polocek 1980). The pasture was lightly grazed by cattle prior to and during the study. The climate in Edwards County is semiarid with average rainfall of about $41 \mathrm{~cm}$. Major grasses on the common curleymesquitegrass-threeawn-liveoak community were common curlymesquitegrass and threeawn. Major browse species were liveoak, algerita (Berberis trifoliolata), junipcr (Juniperus spp.), lotcbush (Condalia obtusifolia), Texas persimmon (Diosypros texana), and elbowbush (Forestiera pubescens).

The mixed grass-honey mesquite community was in a 24-ha pasture $3.7 \mathrm{~km}$ north of San Angelo in Tom Green County. The climate is semiarid with average annual rainfall of about $46 \mathrm{~cm}$. The Angelo clay loam soils were on nearly level to gently sloping terrain (Weidenfeld and Flores 1976). The Clay Loam range site 
supported a wide variety of browse species and had been lightly grazed by sheep and goats prior to this study. Major grasses on the mixed grass-mesquite community were tobosagrass (Hilaria mutica), sideoats grama (Bouteloua curtipendula), and threeawns. Other important grasses were buffalograss (Buchloe dactyloides), sand dropseed (Sporobolus cryptandrus), and common curlymesquitegrass. Major forbs were huisache daisy (Amblyolepis setigera), plantain (Plantago sp.), pepperweed (Lepidium densiflorum), Nuttall milkvetch (Astragalus nuttallianus), and bladderpod (Lesquerella gracilis). Major shrubs were honey mesquite, littleleaf sumac (Rhus microphylla), algerita, lotebush and catclaw acacia (Acacia greggii).

The creosotebush-tarbush community was in a 28 -ha pasture on the Phillip Robbins Ranch, $13.7 \mathrm{~km}$ southeast of Fort Stockton in Pecos County. The climate is arid to semiarid with an average annual precipitation of about $31 \mathrm{~cm}$. Soils on the Limestone Hill and Mountain Range site were of the Ector series, which are very shallow to shallow, well drained, loamy soils on slopes of 1 to $35 \%$ (Rives 1980). The major grasses were burrograss (Scleropogon brevifolius), threeawns, and tobosagrass. Major forbs were grassland croton (Croton dioicus), prickleaf dogweed (Dyssodia acerosa), and lanceleaf sage (Salvia reflexa). Creosotebush and tarbush were the most common shrubs.

\section{Diet Analyses}

Botanical composition of sheep and goat diets was determined by analysis of fecal material using the microhistological technique as described by Sparks and Malechek (1968). Extensive research indicates that certain plants fragment differently when undergoing the digestive process, thus creating biases when feces is used to estimate diets (Anthony and Smith 1974, Westoby et al. 1976, Vavra et al. 1978, Holechek et al. 1982). Even though we assume biases exist, several methods have been developed to correct such distortions (Vavra et al. 1978, Holechek et al. 1982). Dietary trends and relative importance of forage plants are accurate when using feces to estimate diets (Vavra et al. 1978). In the authors'opinion, the microscopic examination of fecal material was adequate for accomplishing the objective of this study.

Yearling female Rambouillet, Karakul, and Barbado sheep and Spanish and Angora goats were allowed to graze for 7 to 14 days on each study area prior to collection of fecal samples. Fecal samples, consisting of about $5 \mathrm{gm}$, were collected daily by rectal-phalangeal extraction from 5 to 10 animals of each breed during each 5-day collection period. Each sample consisted of a composite of 5 individual fecal samples from each animal of the 5 different breeds. Fecal samples were collected during a single season at the Pecos and Edwards County locations and 2 seasons at the Tom Green County location. Mean diets for each breed of sheep and goat were calculated for each collection period along with 2 standard errors (SE) of these means. Means with non-overlapping confidence intervals were considered significantly different.

Similarity of diets was calculated using Kulczyniski's similarity index (Oosting 1956). The formula,

$$
\frac{2 \sum_{i=1}^{s} w_{i}(100)}{\sum_{i=1}^{s} a_{i}+b_{i}}
$$

was used to estimate dietary overlap among the 5 sheep and goat breeds, where $a_{i}$ represents the mean percentage of food item $i$ in the diet of breed $\mathrm{X}, \mathrm{b}_{i}$ represents the mean percentage of food item $i$ in the diet of breed $\mathrm{Y}$, with $w_{i}$ represents $a_{i}$ if $a_{i}<b_{i}$ and $b_{i}$ if $b_{i}<a_{i}$.

\section{Herbage Availability}

Herbage availability was determined during most fecal collection periods by harvesting individual species of grasses and forbs in each of 75 randomly located, $0.25-\mathrm{m}^{2}$ quadrats and browse in each of $75,1-\mathrm{m}^{2}$ quadrats. Samples were dried at $60^{\circ} \mathrm{C}$ for $48 \mathrm{~h}$ then weighed. Mean standing crops $( \pm 2 S E$ ) were calculated in $\mathrm{kg} / \mathrm{ha}$ for all species. Sampling was inadequate to estimate availability of rare or occasional plant species that occurred in sheep and goat diets.
Spearman's rank correlation (RHO) was used to determine whether availability of plant species significantly correlated with animal diets. The rank correlation was assumed to estimate degree of concordance ( $\mathrm{RHO}=+$ value) or discordance ( $\mathrm{RHO}=-$ value) of the animal diets with available food resources (Snedecor and Cochran 1973). Rank order correlations were calculated for each fecal collection period.

\section{Results and Discussion}

\section{Animal Diets \\ Common Curlymesquitegrass-Threeawn-Liveoak Community}

Dry grasses, mostly threeawns and common curlymesquitegrass, accounted for $99 \%$ of the available herbage during the dry autumn 1979 and winter 1980 on the Edwards County study area (Table 1). No forbs were recorded and algerita was the only browse

Table 1. Mean ( $\pm 2 S E$ ) standing crop of herbage (kg/ha) in common curlymesquite-threeawn-liveoak community in Edwards County, Texas.

\begin{tabular}{ll}
\hline \hline Forage species & February 1980 \\
\hline Grasses & $(\mathrm{kg} / \mathrm{ha})$ \\
Hilaria belangeri & $242 \pm 68$ \\
Aristida spp. & $184 \pm 60$ \\
Bouteloua curtipendula & $36 \pm 36$ \\
Panicum obtusum & $55 \pm 56$ \\
Bothriochloa saccharoides & $13 \pm 16$ \\
$\quad$ Total grasses & 530 \\
Forbs & 0 \\
Browse & \\
Berberis trifoliolata & $6 \pm 13$ \\
Total browse & 6 \\
\hline
\end{tabular}

species that occurred in the sampled quadrats.

Rambouillet and Karakul sheep, along with Angora goats consumed significantly more grass and grasslike plants compared to Spanish goats and Barbado sheep during November 1979, whereas Barbado sheep and Spanish goats consumed significantly more browse (Table 2 ). The sheep breeds consumed significantly more sedge (Carex spp.) than the goat breeds during November, while the goats consumed significantly more Texas wintergrass (Stipa leucotricha). Spanish goat diets included significantly more oak than those of Angora goats or Rambouillet and Karakul sheep, and significantly more Texas persimmon than any of the other breeds in November (Table 2).

Angora goats, as well as all sheep breeds consumed significantly more grass and grasslike plants compared to the Spanish goats in February 1980 (Table 2). All sheep breeds consumed more sedge than the goat breeds, and Angora goats relied mote heavily on sedge than Spanish goats. Texas wintergrass, threeawns, and common curlymesquitegrass were significantly less important in diets of Spanish goats compared to the other breeds. Spanish goats consumed significantly more browse than all other breeds during February 1980 (Table 2). Oak was more important in Spanish goat diets than in diets of all other breeds and Angora goats consumed significantly more oak than the sheep breeds. Barbado sheep consumed significantly more browse than the other sheep breeds. Juniper was an important food of all breeds during February 1980.

Forbs, which were rare on the study area, were a minor constituent of the diets for all breeds in the common curlymesquitegrassthreeawn-liveoak community during the winter of 1979-80.

\section{Mixed Grass-Honey Mesquite Community}

Forage conditions were below normal due to lack of rainfall and above-average temperatures in the mixed grass-honey mesquite community during the spring-summer season of 1980 . Grasses made up about $90 \%$ and $84 \%$ respectively, of total available her- 
Table 2. Mean ( $\pm 2 S E$ ) diet composition (\%) of five different breeds of sheep and goats grazing in a common curlymesquitegrass-threeawn-liveoak community in Edwards County, Texas.

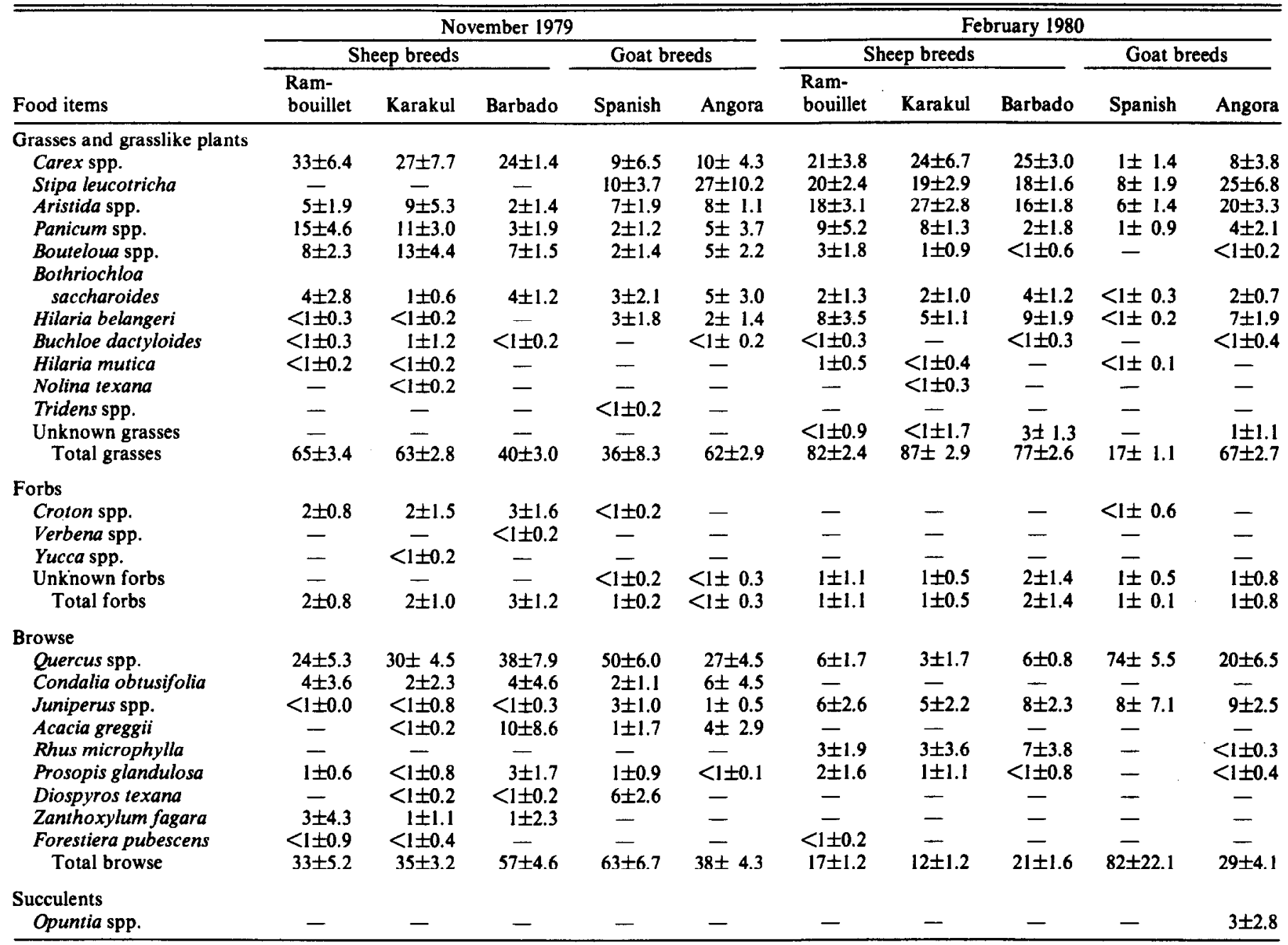

Table 3. Mean ( $\pm 2 \mathrm{SE})$ standing crop of herbage $(\mathrm{kg} / \mathrm{ha})$ in a mixed grass-mesquite community in Tom Green County, Texas.

bage of the spring and summer seasons (Table 3). Browse, mainly honey mesquite, contributed about $3 \%$ and $13 \%$, respectively. to available herbage during the two seasons.

Rambouillet and Karakul sheep diets contained significantly more grass than those of Barbado sheep or the goat breeds during April 1980 (Table 4). Barbado sheep consumed more grass than the goat breeds and Angora goats consumed significantly more grass than Spanish goats. Grama grasses (Bouteloua spp.) were more important in sheep diets than in goat diets, whereas Ozarkgrass (Limnodea arkansana) was more important in goat diets. Karakul sheep consumed significantly more tobosagrass than did Barbado sheep and the goat breeds. Forbs were more important in diets of the sheep breeds compared to Angora and Spanish goats, and Karakul sheep diets contained significantly less forbs than those of Rambouillet or Barbado sheep (Table 4). Spanish and Angora goats relied mote heavily on browse in April 1980 than did the sheep breeds, and Barbado sheep consumed significantly more browse than did the other sheep breeds. Littleleaf sumac was the major browse plant consumed by all breeds. Honey mesquite was present in trace amounts in diets of Karakul sheep and Angora goats.

During August 1980, Spanish goats also consumed significantly less grass and more browse than the other breeds (Table 4). Grasses contributed about half the diets of the sheep breeds and Angora goats, but only one-fourth the diets of Spanish goats. Major grasses in diets of all breeds included grama grasses, sand drop-

\begin{tabular}{|c|c|c|}
\hline Forage species & $\begin{array}{r}\text { April } 1980 \\
\text { (kg/ha) }\end{array}$ & $\begin{array}{c}\text { August } 1980 \\
(\mathrm{~kg} / \mathrm{ha})\end{array}$ \\
\hline $\begin{array}{l}\text { Grasses } \\
\text { Hilaria mutica } \\
\text { Aristida spp. } \\
\text { Bouteloua curtipendula } \\
\text { Buchloe dactyloides } \\
\text { Hilaria belangeri } \\
\text { Sporobolus cryptandrus } \\
\text { Stipa leucotricha } \\
\text { Limnodea arkansana } \\
\text { Leptochloa dubia } \\
\text { Tridens spp. } \\
\text { Bothriochloa saccharoides } \\
\text { Muhlenbergia spp. } \\
\text { Chloris cucullata } \\
\text { Total grasses }\end{array}$ & $\begin{array}{c}750 \pm 236 \\
207 \pm 116 \\
65 \pm 64 \\
67 \pm 68 \\
23 \pm 24 \\
- \\
47 \pm 40 \\
51 \pm 20 \\
39 \pm 40 \\
= \\
6 \pm 8 \\
= \\
1,255\end{array}$ & $\begin{array}{c}488 \pm 280 \\
125 \pm 64 \\
181 \pm 100 \\
84 \pm 56 \\
41 \pm 40 \\
59 \pm 72 \\
5 \pm 8 \\
- \\
- \\
28 \pm 76 \\
26 \pm 52 \\
-\overline{4} \\
1,041\end{array}$ \\
\hline $\begin{array}{l}\text { Forbs } \\
\text { Miscellaneous forbs } \\
\text { Total forbs }\end{array}$ & $\begin{array}{l}77 \\
77\end{array}$ & $\overline{-}$ \\
\hline $\begin{array}{l}\text { Browse } \\
\text { Prosopis glandulosa } \\
\text { Condalia obtusifolia } \\
\text { Berberis trifoliolata } \\
\text { Rhus microphylla } \\
\text { Acacia greggii } \\
\text { Ephedra spp. } \\
\text { Total browse }\end{array}$ & $\begin{array}{c}38 \pm 51 \\
1 \pm 2 \\
4 \pm 8 \\
- \\
5 \pm 14 \\
2 \pm 2 \\
50\end{array}$ & $\begin{array}{c}164 \pm 33 \\
16 \pm 6 \\
10 \pm 4 \\
8 \pm 3 \\
4 \pm 6 \\
- \\
202\end{array}$ \\
\hline
\end{tabular}


Table 4. Mean ( \pm 2 SE) diet composition (\%) of five different breeds of sheep and goats graing in a mixed grass-mesquite community in Tom Green County, Texas.

\begin{tabular}{|c|c|c|c|c|c|c|c|c|c|c|}
\hline \multirow[b]{3}{*}{ Food items } & \multicolumn{5}{|c|}{ April 1980} & \multicolumn{5}{|c|}{ August 1980} \\
\hline & \multicolumn{3}{|c|}{ Sheep breeds } & \multicolumn{2}{|c|}{ Goat breeds } & \multicolumn{3}{|c|}{ Sheep breeds } & \multicolumn{2}{|c|}{ Goat breeds } \\
\hline & $\begin{array}{l}\text { Ram- } \\
\text { bouillet }\end{array}$ & Karakul & Barbado & Spanish & Angora & $\begin{array}{l}\text { Ram- } \\
\text { bouillet }\end{array}$ & Karakul & Barbado & Spanish & Angora \\
\hline \multicolumn{11}{|l|}{ Grasses and grasslike plants } \\
\hline Bouteloua spp. & $46 \pm 3.7$ & $46 \pm 2.8$ & $36 \pm 3.2$ & $9 \pm 2.6$ & $12 \pm 5.5$ & $36 \pm 10.2$ & $36 \pm 3.4$ & $31 \pm 2.6$ & $12 \pm 3.8$ & $24 \pm 7.8$ \\
\hline Stipa kucotricha & - & $<1 \pm 0.7$ & $<1 \pm 0.5$ & $2 \pm 0.9$ & $1 \pm 1.0$ & & $<1 \pm 0.2$ & $<1 \pm 0.3$ & $<1 \pm 0.2$ & $<1 \pm 0.3$ \\
\hline Sporobolus cryptandrus & $2 \pm 0.9$ & $2 \pm 1.2$ & $3 \pm 1.2$ & $<1 \pm 0.8$ & $2 \pm 1.2$ & $2 \pm 1.0$ & $4 \pm 1.8$ & $2 \pm 1.2$ & $6 \pm 0.9$ & $13 \pm 2.9$ \\
\hline Aristida spp. & $2 \pm 2.8$ & $2 \pm 1.9$ & $<1 \pm 0.3$ & $<1 \pm 0.5$ & $<1 \pm 0.5$ & $3 \pm 2.4$ & $1 \pm 0.9$ & $2 \pm 2.0$ & $1 \pm 1.5$ & $3 \pm 1.7$ \\
\hline Hilaria belangeri & $2 \pm 1.0$ & $6 \pm 5.3$ & $4 \pm 2.0$ & $2 \pm 1.6$ & $3 \pm 1.7$ & $6 \pm 1.5$ & $6 \pm 2.4$ & $4 \pm 1.2$ & $3 \pm 1.0$ & $6 \pm 1.6$ \\
\hline Limnodea arkansana & $3 \pm 2.2$ & $4 \pm 0.6$ & $2 \pm 0.9$ & $7 \pm 1.3$ & $9 \pm 0.9$ & - & - & - & - & - \\
\hline Buchloe dactyloides & $6 \pm 3.2$ & $6 \pm 1.9$ & $2 \pm 1.2$ & $<1 \pm 0.4$ & $<1 \pm 0.3$ & $<1 \pm 0.7$ & $2 \pm 0.8$ & $2 \pm 0.8$ & $<1 \pm 0.2$ & $<1 \pm 0.4$ \\
\hline Hilaria mutica & $6 \pm 4.5$ & $7 \pm 1.8$ & $2 \pm 0.8$ & $<1 \pm 0.5$ & $<1 \pm 0.3$ & $1 \pm 2.5$ & $2 \pm 2.1$ & $2 \pm 1.1$ & $<1 \pm 0.4$ & $<1 \pm 0.2$ \\
\hline $\begin{array}{l}\text { Bothriochloa } \\
\text { saccharoides }\end{array}$ & - & - & - & - & - & $<1 \pm 0.3$ & $<1 \pm 0.2$ & $<1 \pm 0.3$ & $<1 \pm 0.3$ & $<1 \pm 1.0$ \\
\hline Panicum spp. & $3 \pm 2.0$ & $2 \pm 1.3$ & - & - & - & $<1 \pm 0.3$ & $<1 \pm 0.2$ & $<\mathrm{I} \pm 0.5$ & $1 \pm 0.4$ & $<1 \pm 0.9$ \\
\hline Bromus unioloides & $1 \pm 2.0$ & $1 \pm 1.1$ & $<1 \pm 0.7$ & $1 \pm 0.6$ & $2 \pm 1.7$ & - & - & - & - & - \\
\hline Phalaris canariensis & $<1 \pm 0.2$ & - & - & $<1 \pm 0.4$ & $2 \pm 0.7$ & - & - & - & - & - \\
\hline Unknown grasses & $2 \pm 1.4$ & $<1 \pm 0.6$ & $2 \pm 1.4$ & $<1 \pm 0.4$ & $<1 \pm 0.6$ & $<1 \pm 0.6$ & - & $<1 \pm 0.2$ & $<1 \pm 0.2$ & $<1 \pm 0.3$ \\
\hline Total grasses & $73 \pm 3.5$ & $77 \pm 3.5$ & $52 \pm 3.4$ & $24 \pm 0.9$ & $32 \pm 2.1$ & $49 \pm 3.5$ & $52 \pm 3.3$ & $45 \pm 2.6$ & $25 \pm 1.1$ & $50 \pm 2.3$ \\
\hline \multicolumn{11}{|l|}{ Forbs } \\
\hline Sphaeralcea spp. & $10 \pm 3.0$ & $3 \pm 1.3$ & $12 \pm 3.1$ & $6 \pm 1.7$ & $4 \pm 2.6$ & $13 \pm 6.4$ & $16 \pm 6.9$ & $19 \pm 6.4$ & $4 \pm 1.1$ & $3 \pm 2.7$ \\
\hline Plantago rhodosperma & $<1 \pm 0.2$ & $<1 \pm 0.4$ & $1 \pm 0.5$ & - & $<1 \pm 0.8$ & - & $<1 \pm 0.2$ & - & - & - \\
\hline Abutilon incanum & $6 \pm 2.4$ & $7 \pm 1.0$ & $10 \pm 4.5$ & $1 \pm 1.1$ & $3 \pm 2.7$ & $7 \pm 1.2$ & $<1 \pm 1.1$ & $1 \pm 1.1$ & $1 \pm 1.5$ & $3 \pm 1.6$ \\
\hline Verbena bipinnatifida & $<1 \pm 0.6$ & - & - & - & - & - & - & - & - & - \\
\hline Unknown forbs & $4 \pm 1.0$ & $4 \pm 0.6$ & $5 \pm 2.4$ & $1 \pm 0.6$ & $2 \pm 1.3$ & $3 \pm 1.1$ & $3 \pm 0.8$ & $3 \pm 0.8$ & $2 \pm 0.6$ & $3 \pm 1.3$ \\
\hline Total forbs & $20 \pm 1.6$ & $15 \pm 1.2$ & $28 \pm 2.4$ & $8 \pm 1.4$ & $9 \pm 1.1$ & $23 \pm 3.4$ & $19 \pm 3.3$ & $23 \pm 4.7$ & $7 \pm 0.9$ & $9 \pm 0.7$ \\
\hline \multicolumn{11}{|l|}{ Browse } \\
\hline Rhus microphylla & $7 \pm 3.1$ & $8 \pm 3.8$ & $20 \pm 2.5$ & $68 \pm 7.4$ & $59 \pm 11.2$ & $24 \pm 5.2$ & $26 \pm 4.3$ & $30 \pm 2.8$ & $60 \pm 5.4$ & $39 \pm 6.0$ \\
\hline Prosopis glandulosa & - & $<1 \pm 0.3$ & - & - & $<1 \pm 0.2$ & $4 \pm 1.6$ & $3 \pm 2.9$ & $2 \pm 1.5$ & $<1 \pm 0.2$ & - \\
\hline Condalia obtusifolia & - & - & - & - & - & - & - & - & $2 \pm 0.8$ & - \\
\hline Acacia greggii & - & - & - & - & - & - & - & $<1 \pm 1.2$ & $6 \pm 1.0$ & $2 \pm 1.6$ \\
\hline Celtis reticulata & - & - & - & 一 & - & - & $<1 \pm 0.4$ & - & - & - \\
\hline Total browse & $7 \pm 3.1$ & $8 \pm 3.1$ & $20 \pm 2.5$ & $68 \pm 7.4$ & $59 \pm 20.3$ & $28 \pm 7.2$ & $29 \pm 6.3$ & $32 \pm 8.9$ & $68 \pm 11.5$ & $41 \pm 12.5$ \\
\hline \multicolumn{11}{|l|}{ Succulents } \\
\hline Opuntia spp. & - & - & - & - & - & - & - & - & $2 \pm 0.8$ & $1 \pm 1.3$ \\
\hline
\end{tabular}

seed, and common curlymesquitegrass. Forbs, primarily globemallows (Sphaeralcea spp.), were significantly more important in sheep diets compared to goat diets. Littleleaf sumac continued to be the major browse of all breeds. Honey mesquite was move important in diets of sheep, compared to goats. Spanish goats consumed significantly more catclaw acacia and lotebush than did Angora goats or the sheep breeds. Pricklypear (Opuntia spp.) occurred in trace amounts in diets of Spanish and Angora goats (Table 4).

Forage conditions were excellent after seasonal rains in the late winter-spring 1981 in the mixed grass-honey mesquite community. Grasses, primarily tobasagrass, contributed about $78 \%$ of the total herbage during the early spring 1981 (Table 5). Forb production, mainly huisachedaisy and plaintain, incrcased to contribute about $66 \%$ of total herbage by April 1981 .

Diets of all sheep and goat breeds were most varied during the late-winter and spring of 1981 in the mixed grass-mesquite community (Table 6). During February 1981, grasses were the staple food of all breeds. Grasses made up about $80 \%$ of the diets of the sheep breeds and Angora goats, but Spanish goats consumed significantly less grass (68\%). Texas wintergrass was more important in diets of Barbado sheep and the goat breeds than in those of Rambouillet or Karakul sheep. Rambouillet and Karakul sheep tended to rely more heavily on threeawns, common curlymesquitegrass, buffalograss, and silver bluestem (Bothriochloa saccharoides). Forbs, primarily bladderpods contributed 11 to $14 \%$ of the diets of the sheep and goats. Browse, primarily Morman tea (Ephedra spp.), honey mesquite, and littleleaf sumac, was impor- tant in the diets of all sheep and goat breeds, but Spanish goats consumed significantly more browse than the other breeds (Table $6)$.

During April 1981, grasses continued to be the staple food of all breeds, but forbs increased considerably in dietary importance (Table 6). Karakul and Barbado sheep consumed significantly more grass than all other breeds, while Rambouillet sheep consumed more grass than did the goat breeds. All sheep and goat breeds opportunistically utilized a variety of forbs. Forbs were more important in Rambouillet sheep diets compared to diets of all other breeds; Karakul and Barbado sheep ate significantly more forbs than did the goat breeds. Browse, primarily littleleaf sumac and lotebush, were major foods of Spanish and Angora goats. The goat breeds consumed significantly more browse compared to the sheep breeds, while Karakul sheep tended to consume less browse than did Rambouillet or Barbado sheep (Table 6).

\section{Creosotebush-Tarbush Community}

About $10 \mathrm{~cm}$ of rain fell the week prior to collection of diet samples in late-summer 1980 in the creosotebush-tarbush community. Grasses, primarily burrograss, contributed $65 \%$ of available herbage, while forbs and browse contributed $9 \%$ and $26 \%$, respectively (Table 7 ).

A variety of grasses comprised the major diet component of all sheep and goat breeds during September 1980 in the creosotebushtarbush community (Table 8 ). Grasses were significantly more important in sheep diets than in goat diets, and also more important in diets of Angora goats compared to Spanish goats. Spanish 
Table 5. Mean ( $\pm 2 \mathrm{SE})$ standing crop of herbage $(\mathrm{kg} / \mathrm{ha})$ in a mixed grass-mesquite community in Tom Green, Texas.

\begin{tabular}{|c|c|c|}
\hline Forage species & $\begin{array}{c}\text { February } 1981 \\
(\mathrm{~kg} / \mathrm{ha})\end{array}$ & $\begin{array}{l}\text { April } 1981 \\
(\mathrm{~kg} / \mathrm{ha})\end{array}$ \\
\hline $\begin{array}{l}\text { Grasses } \\
\text { Hilaria mutica } \\
\text { Aristida spp. } \\
\text { Buchloe dactyloides } \\
\text { Bouteloua curtipendula } \\
\text { Stipa leucotricha } \\
\text { Limnodea arkansana } \\
\text { Hilaria belangeri } \\
\text { Bromus unioloides } \\
\text { Tridens spp. } \\
\text { Muhlenbergia spp. } \\
\text { Total grasses }\end{array}$ & $\begin{array}{c}878 \pm 340 \\
146 \pm 132 \\
31 \pm 56 \\
60 \pm 76 \\
19 \pm 24 \\
- \\
37 \pm 44 \\
6 \pm 12 \\
- \\
2 \pm 4 \\
1,195\end{array}$ & $\begin{array}{l}749 \pm 283 \\
16 \pm 11 \\
54 \pm 29 \\
17 \pm 32 \\
36 \pm 59 \\
52 \pm 30 \\
1 \pm 1 \\
22 \pm 37 \\
6 \pm 10 \\
2 \pm 15 \\
956\end{array}$ \\
\hline $\begin{array}{l}\text { Forbs } \\
\text { Amblyolepis setigera } \\
\text { Plantago rhodosperma } \\
\text { Astragalus nuttallianus } \\
\text { Lepidium densiflorum } \\
\text { Lesquerella gracilis } \\
\text { Oenothera spp. } \\
\text { Nama hispidum } \\
\text { Ammoselinum popei } \\
\text { Lappula redowskii } \\
\text { Linim lewisii } \\
\text { Verbena bipinnatifida } \\
\text { Evax prolifera } \\
\text { Miscellaneous forbs } \\
\text { Total forbs }\end{array}$ & $\begin{array}{c}194 \pm 17 \\
55 \pm 6 \\
10 \pm 2 \\
- \\
- \\
- \\
- \\
- \\
- \\
- \\
- \\
- \\
61 \pm 7 \\
320\end{array}$ & $\begin{array}{c}851 \pm 54 \\
258 \pm 27 \\
171 \pm 16 \\
158 \pm 22 \\
134 \pm 22 \\
63 \pm 14 \\
43 \pm 11 \\
40 \pm 9 \\
39 \pm 11 \\
35 \pm 7 \\
22 \pm 14 \\
21 \pm 4 \\
207 \pm 1 \\
2,041\end{array}$ \\
\hline $\begin{array}{l}\text { Bruwse } \\
\text { Prosopis glandulosa } \\
\text { Ephedra spp. } \\
\text { Berberis trifoliolata } \\
\text { Rhus microphylla } \\
\text { Condalia obtusifolia } \\
\text { Lycium texanum } \\
\text { Total browse }\end{array}$ & $\begin{array}{c}- \\
12 \pm 5 \\
5 \pm 5 \\
- \\
- \\
- \\
17\end{array}$ & $\begin{array}{c}68 \pm 16 \\
3 \pm 1 \\
4 \pm 2 \\
8 \pm 3 \\
7 \pm 3 \\
1 \pm 0.3 \\
91\end{array}$ \\
\hline
\end{tabular}

goats tended to rely more heavily on forbs, primarily spreading sida (Sida filicaulis), than did the other breeds. Browse was significantly more important in goat diets compared to sheep diets, and Barbado sheep consumed significantly more browse than did the other sheep breeds. Littleaf sumac was the major browse plant of both goat breeds and Barbado sheep. Tarbush was not eaten by any of the breeds of sheep or goats, and creosotebush was only present in trace amounts in Barbado sheep diets (Table 8).

Forbs increased considerably in importance in the diets of all breeds during November 1980 in the creosotebush-tarbush community (Table 8). Rambouillet sheep ate significantly more forbs than the other breeds, while Karakul sheep ate more forbs than Barbado sheep or the goats. Forbs were least important in diets of Spanish goats. Grasses were significantly more important in diets of Barbado sheep and Angora goats compared to the other breeds, while they were least important in diets of Rambouillet sheep. Spanish goats consumed significantly more browse than all other breeds, while Angora goats and Barbado sheep consumed more browse than did Rambouillet and Karakul sheep. Littleleaf sumac, wolfberry (Lycium texanum), redberry juniper (Juniperus pinchotii), and javelinabrush (Microrhamnus ericoides) were the major browse plants in goat and sheep diets. Tarbush occurred in trace amounts in Barbado sheep diets, whereas creosotebush was not present in diets of any of the breeds (Table 8).

\section{Dietary Overlap}

Dietary similarity. indices computed over sampling periods within plant communities indicated that diets of Rambouillet and
Karakul sheep overlapped considerably, while the diets of Rambouillet sheep and Spanish goats were the least similar (Table 9). Diets of Barbado sheep and Angora goats overlapped to the same degree as diets of Angora and Spanish goats. Diets of Angora goats and Barbado sheep overlapped more in the mixed grass-mesquite community than in the other 2 communities. Barbado sheep generally utilized more browse than Rambouillet or Karakul sheep, thereby occupying a food niche intermediate between those of Rambouillet and Karakul sheep and Spanish and Angora goats. The relatively low dietary overlap between Spanish and Angora goats in the common curlymesquitegrass-threeawn-liveoak community (Edwards County) may be explained by limited availability of browse due to an elevated browse line.

\section{Food Niche Dimensions}

The mean number of different plant species in the diets of Rambouillet, Karakul, and Barbado sheep, averaged across all 3 plant communities and sampling periods, was 18 , compared to 18.5 for Angora goats and 19 for Spanish goats, indicating no biologically important deviation among these breeds in respect to the number of different food plants. However, considerable variation was observed in numbers of different foods in diets of all breeds among plant communities and among sampling dates within plant communities. These differences were attributed to (1) difference in relative abundance of plant species among the 3 communities and among sampling dates, (2) changes in acceptability of certain plants to sheep and goats over time, and/or (3) inherent tendencies of the herbivores to voluntarily shift grazing behavior over time.

\section{Association of Diets and Herbage Availability}

Spearman's rank order correlation coefficients range from -1 to +1 . A coefficient of -1 is interpreted as an inverse relationship of diet to availablity of foods, hence a high degree of food selectivity. A correlation coefficient of 0 indicates no relationship between diet and food availability, hence suggesting that diet is determined by inherent preference for certain foods, regardless of their relative availability. $A+1$ value is interpreted as a direct positive relationship between diet and food availability and indicates random feeding.

In most cases, Spearman's rank order correlation coefficients of sheep and goat diets with herbage availability were not significantly different from $0(P<0.10)$ (Table 10$)$ indicating selective grazing among the sheep and goat breeds studied. Spanish and Angora goats exhibited the strongest tendency to selectively graze in the plant communities studied, based on mean correlation coefficients of 0.12 and 0.14 , respectively (Table 10). Karakul sheep exhibited the least tendency to selectively graze (mean $=0.31$ ), where Rambouillet and Barbado sheep were intermediate in this regard (mean $=0.22$ ).

Spearman's rank order correlation coefficients were lowest for sheep and goats grazing in the creosotebush-tarbush community (mean $=0.03$ ) and highest in the common curlymesquitegrassthreeawn-liveoak community (mean $=0.36$ ), apparently reflecting the variation in forage diversity among these two study sites. Forage diversity (the number of plant species) was much greater in the creosotebush-tarbush community than in the common curlymesquitegrass-threeawn-liveoak community during the periods diet samples were collected. The increased plant diversity in the creosotebush-tarbush community apparently allowed the phenotypic expression of the inherent tendency of all 5 breeds of sheep and goats to selectively graze; whereas, the lack of plant diversity in the common curlymesquitegrass-threeawn-liveoak community prohibited the phenotypic expression of diet selectivity among the breeds. 
Table 6. Mean ( $\pm 2 \mathrm{SE}$ ) diet composition $(\%)$ of five different breods of sheep and gonts graxing in a mixed grass-mesquite community in Tom Green County, Texas.

\begin{tabular}{|c|c|c|c|c|c|c|c|c|c|c|}
\hline \multirow[b]{3}{*}{ Food items } & \multicolumn{5}{|c|}{ February 1981} & \multicolumn{5}{|c|}{ April 1981} \\
\hline & \multicolumn{3}{|c|}{ Sheep breeds } & \multicolumn{2}{|c|}{ Goat breeds } & \multicolumn{3}{|c|}{ Sheep breeds } & \multicolumn{2}{|c|}{ Goat breeds } \\
\hline & $\begin{array}{l}\text { Ram- } \\
\text { bouillet }\end{array}$ & Karakul & Barbado & Spanish & Angora & $\begin{array}{l}\text { Ram- } \\
\text { bouillet }\end{array}$ & Karakul & Barbado & Spanish & Angora \\
\hline \multicolumn{11}{|l|}{ Grasses and grasslike plants } \\
\hline Bouteloua spp. & $9 \pm 4.4$ & $6 \pm 5.7$ & $9 \pm 0.7$ & $4 \pm 2.7$ & $5 \pm 3.3$ & $10 \pm 1.8$ & $13 \pm 2.9$ & $9 \pm 1.3$ & $3 \pm 1.2$ & $10 \pm 1.0$ \\
\hline Stlpa leucotricha & $17 \pm 4.7$ & $17 \pm 8.9$ & $42 \pm 4.5$ & 38 土5.8 & $42 \pm 7.3$ & $8 \pm 1.8$ & $14 \pm 4.0$ & $15 \pm 2.2$ & $11 \pm 5.1$ & $11 \pm 4.9$ \\
\hline Sporobolus cryptandrus & $5 \pm 2.1$ & $9 \pm 3.1$ & $8 \pm 2.4$ & $13 \pm 4.3$ & $13 \pm 3.0$ & $13 \pm 3.4$ & $11 \pm 2.0$ & $7 \pm 1.9$ & $1 \pm 1.0$ & $1 \pm 0.9$ \\
\hline Aristida spp. & $18 \pm 4.0$ & $12 \pm 2.5$ & $10 \pm 2.2$ & $6 \pm 2.1$ & $7 \pm 3.0$ & $5 \pm 2.1$ & $5 \pm 2.5$ & $7 \pm 2.3$ & $4 \pm 1.3$ & $4 \pm 2.4$ \\
\hline Hilaria belangeri & $10 \pm 3.4$ & $17 \pm 5.5$ & $6 \pm 3.5$ & $3 \pm 2.0$ & $4 \pm 1.9$ & $2 \pm 1.0$ & $1 \pm 0.4$ & $<\tilde{i} \pm \overline{\mathbf{u}} . \overline{\mathrm{l}}$ & $<\bar{i} \pm \overline{0} . \overline{7}$ & $<\hat{1} \pm \hat{0} .7$ \\
\hline Tridens spp. & - & - & $<1 \pm 0.3$ & - & $<1 \pm 0.2$ & $7 \pm 4.0$ & $18 \pm 2.8$ & $19 \pm 1.4$ & $16 \pm 14.0$ & $12 \pm 1.5$ \\
\hline Limnodea arkansana & $<1 \pm 0.5$ & $2 \pm 2.2$ & - & $1 \pm 0.7$ & $<1 \pm 0.3$ & $9 \pm 1.8$ & $5 \pm 1.1$ & $7 \pm 1.9$ & $3 \pm 2.0$ & $6 \pm 2.7$ \\
\hline Buchloe dactyloides & $4 \pm 2.9$ & $7 \pm 2.6$ & $2 \pm 2.0$ & $2 \pm 1.2$ & $1 \pm 0.9$ & $1 \pm 0.4$ & $<1 \pm 0.3$ & $2 \pm 1.2$ & $<1 \pm 0.5$ & $1 \pm 1.0$ \\
\hline Hilaria mutica & $2 \pm 1.5$ & $3 \pm 0.9$ & $<1 \pm 0.7$ & $<1 \pm 1.1$ & $1 \pm 1.0$ & $<1 \pm 0.3$ & $<1 \pm 0.3$ & $<1 \pm 0.2$ & $1 \pm 0.9$ & $<1 \pm 0.3$ \\
\hline $\begin{array}{l}\text { Bothriochloa } \\
\text { saccharoides }\end{array}$ & 5 & +1.5 & $1+1.2$ & $<1 \pm 0.3$ & $1 \pm 1.3$ & $<1 \pm 0.5$ & $<1 \pm 0.8$ & - & $<1 \pm 0.5$ & - \\
\hline $\begin{array}{l}\text { Paccharo iates } \\
\text { Panicum spp. }\end{array}$ & $\begin{array}{r}10 \pm 0.3 \\
3 \pm 2.4\end{array}$ & $1 \pm 0.5$ & $2 \pm 1.3$ & $1 \pm 1.1$ & $<1 \pm 0.6$ & $1 \pm 1.0$ & $<1 \pm 0.3$ & $<1 \pm 0.2$ & $<1 \pm 0.5$ & $<\overline{1 \pm 0.2}$ \\
\hline Total grasses & $78 \pm 3.5$ & $77 \pm 2.0$ & $80 \pm 3.5$ & $68 \pm 3.2$ & $76 \pm 3.2$ & $56 \pm 1.2$ & $70 \pm 1.8$ & $67 \pm 1.8$ & $40 \pm 1.5$ & $45 \pm 1.4$ \\
\hline \multicolumn{11}{|l|}{ Forbs } \\
\hline Sphaeralcea spp. & $<1 \pm 0.8$ & $1 \pm 1.0$ & $3 \pm 1.5$ & $2 \pm 1.4$ & $3 \pm 1.1$ & $2 \pm 1.2$ & $4 \pm 1.8$ & $4 \pm 1.3$ & $3 \pm 1.1$ & $2 \pm 2.8$ \\
\hline Lesquerella gracilis & $9 \pm 3.4$ & $9 \pm 2.2$ & $9 \pm 2.6$ & $7 \pm 1.9$ & $9 \pm 2.0$ & $7 \pm 2.3$ & $6 \pm 1.0$ & $6 \pm 1.1$ & $3 \pm 2.4$ & $3 \pm 2.7$ \\
\hline Plantago rhodosperma & - & - & - & - & - & $8 \pm 2.3$ & $8 \pm 2.9$ & $7 \pm 2.1$ & $8 \pm 2.3$ & $7 \pm 2.8$ \\
\hline Chenopodium album & - & - & - & - & - & $7 \pm 2.0$ & $3 \pm 0.5$ & $2 \pm 1.3$ & - & - \\
\hline Solanum elaeagnifolium & $1 \pm 0.9$ & $<1 \pm 0.4$ & $<1 \pm 0.6$ & $2 \pm 1.3$ & $2 \pm 1.6$ & $<1 \pm 0.7$ & $<1 \pm 0.7$ & $1 \pm 1.2$ & $2 \pm 0.5$ & $3 \pm 0.5$ \\
\hline Corydalis aurea & - & - & - & - & - & $6 \pm 1.4$ & $3 \pm 1.2$ & $2 \pm 1.6$ & $<1 \pm 0.7$ & $<1 \pm 0.3$ \\
\hline Descurania pinnata & - & - & 一 & - & - & $4 \pm 2.7$ & $1 \pm 1.6$ & $2 \pm 1.4$ & - & $<1 \pm 0.2$ \\
\hline Linum lewisii & - & - & - & - & - & $3 \pm 2.9$ & - & - & - & - \\
\hline Perezia mana & - & - & - & - & -- & - & $<1 \pm 0.4$ & $<1 \pm 0.6$ & $1 \pm 1.1$ & $<! \pm ! .1$ \\
\hline Erodium texanum & - & - & - & - & - & - & $<1 \pm 1.0$ & $<1 \pm 0.7$ & $<1 \pm 0.2$ & $<1 \pm 0.4$ \\
\hline Draba cuneifolia & - & - & - & - & - & $<1 \pm 1.2$ & $<1 \pm 0.3$ & $<1 \pm 0.4$ & $<1 \pm 0.2$ & $<1 \pm 0.2$ \\
\hline Amblyolepis setigera & - & - & - & - & - & - & - & $<1 \pm 0.3$ & $<1 \pm 0.2$ & \\
\hline Astragalus nuttallianus & $<1 \pm 0.7$ & - & - & - & - & - & - & $<1 \pm 1.5$ & $<1 \pm 0.3$ & - \\
\hline Ambrosia spp. & $<1 \pm 0.2$ & - & - & - & - & - & $<1 \pm 0.2$ & - & - & - \\
\hline Verbena bipinnatifida & - & - & - & - & - & $<1 \pm 0.5$ & - & - & - & - \\
\hline Englemannia pinnatifida & - & - & - & - & - & $<1 \pm 0.2$ & - & - & - & - \\
\hline Unknown forbs & $<1 \pm 0.8$ & $<1 \pm 0.2$ & - & $<1 \pm 0.9$ & $<1 \pm 0.6$ & $3 \pm 1.0$ & $3 \pm 1.3$ & $4 \pm 0.4$ & $1 \pm 0.4$ & $1 \pm 1.6$ \\
\hline Total forbs & $12 \pm 2.1$ & $11 \pm 1.7$ & $13 \pm 2.1$ & $11 \pm 1.3$ & $14 \pm 1.7$ & $40 \pm 1.0$ & $30 \pm 0.7$ & $29 \pm 0.6$ & $21 \pm 1.6$ & $17 \pm 0.7$ \\
\hline \multicolumn{11}{|l|}{ Browse } \\
\hline Rhus microphylla & $<1 \pm 1.0$ & $3 \pm 2.2$ & $<1 \pm 0.8$ & $9 \pm 2.2$ & $1 \pm 1.9$ & $<1 \pm 0.2$ & - & $1 \pm 1.3$ & $32 \pm 7.4$ & $32 \pm 4.5$ \\
\hline Prosopis glandulosa & $6 \pm 1.6$ & $5 \pm 1.8$ & $1 \pm 1.5$ & $6 \pm 1.7$ & $3 \pm 1.6$ & $<1 \pm 0.4$ & $<1 \pm 0.2$ & - & $<1 \pm 0.6$ & $<1 \pm 0.2$ \\
\hline Ephedra spp. & $4 \pm 3.4$ & $4 \pm 2.2$ & $6 \pm 2.0$ & $6 \pm 2.0$ & $6 \pm 3.3$ & $<1 \pm 0.7$ & $<1 \pm 0.2$ & $2 \pm 1.0$ & $<1 \pm 0.4$ & $<1 \pm 0.2$ \\
\hline Condalia obtusifolia & - & - & - & - & - & $<1 \pm 0.5$ & - & $1 \pm 1.0$ & $6 \pm 2.3$ & $5 \pm 0.8$ \\
\hline Acacia greggii & - & - & - & - & - & $<1 \pm 0.2$ & - & $<1 \pm 0.4$ & $<1 \pm 0.5$ & - \\
\hline Berberis trifoliolata & & & & $<\mathrm{I} \pm 0.2$ & $<1 \pm 1.4$ & - & - & - & $<1 \pm 0.3$ & $<1 \pm 0.2$ \\
\hline Total browse & $10 \pm 1.4$ & $12 \pm 1.2$ & $7 \pm 1.4$ & $21 \pm 1.3$ & $10 \pm 1.3$ & $4 \pm 2.1$ & $1 \pm 0.2$ & $4 \pm 0.7$ & $39 \pm 4.4$ & $38 \pm 5.5$ \\
\hline \multicolumn{11}{|l|}{ Succulents } \\
\hline Opuntia spp. & - & - & - & - & $<1 \pm 1.0$ & - & - & - & $<1 \pm 0.2$ & - \\
\hline
\end{tabular}


Table 8. Mean ( $(2 S E)$ diet composition (\%) of five different breeds of sheep and goats in a creosotebush-tarbush community in Pecos County, Texas.

\begin{tabular}{|c|c|c|c|c|c|c|c|c|c|c|}
\hline \multirow[b]{3}{*}{ Food items } & \multicolumn{5}{|c|}{ September 1980} & \multicolumn{5}{|c|}{ November 1980} \\
\hline & \multicolumn{3}{|c|}{ Sheep breeds } & \multicolumn{2}{|c|}{ Goat breeds } & \multicolumn{3}{|c|}{ Sheep breeds } & \multicolumn{2}{|c|}{ Goat breeds } \\
\hline & $\begin{array}{l}\text { Ram- } \\
\text { bouillet }\end{array}$ & Karakul & Barbado & Spanish & Angora & $\begin{array}{l}\text { Ram- } \\
\text { bouillet }\end{array}$ & Karakul & Barbado & Spanish & Angora \\
\hline \multicolumn{11}{|l|}{ Grasses and grasslike plants } \\
\hline Tridens spp. & $19 \pm 4.6$ & $34 \pm 2.7$ & $15 \pm 4.5$ & $32 \pm 5.5$ & $26 \pm 5.2$ & $3 \pm 1.4$ & $4 \pm 1.4$ & $1 \pm 1.1$ & $<1 \pm 0.6$ & $6 \pm 3.0$ \\
\hline Muhlenbergia spp. & $31 \pm 1.4$ & $11 \pm 4.1$ & $21 \pm 4.2$ & $4 \pm 1.9$ & $17 \pm 4.5$ & $8 \pm 1.2$ & $9 \pm 2.5$ & $7 \pm 1.6$ & $9 \pm 4.2$ & $3 \pm 3.1$ \\
\hline Bouteloua spp. & $12 \pm 3.5$ & $13 \pm 3.0$ & $15 \pm 6.1$ & $7 \pm 1.2$ & $5 \pm 1.3$ & $9 \pm 3.0$ & $12 \pm 2.9$ & $15 \pm 3.4$ & $9 \pm 2.3$ & $16 \pm 6.4$ \\
\hline Scleropogon brevifolius & $5 \pm 0.6$ & $12 \pm 2.6$ & $12 \pm 3.5$ & $8 \pm 2.2$ & $10 \pm 2.1$ & $2 \pm 1.0$ & $3 \pm 1.4$ & $7 \pm 1.4$ & $5 \pm 0.8$ & $6 \pm 3.1$ \\
\hline Erioneuron puchellum & $7 \pm 3.5$ & $4 \pm 3.0$ & $18 \pm 4.5$ & $3 \pm 0.7$ & $5 \pm 2.3$ & $<1 \pm 0.4$ & $1 \pm 0.9$ & $8 \pm 3.1$ & $4 \pm 1.2$ & $2 \pm 0.7$ \\
\hline Enneapogon desvauxii & $9 \pm 2.6$ & $4 \pm 1.5$ & $4 \pm 1.1$ & $6 \pm 1.1$ & $4 \pm 2.3$ & $<1 \pm 0.3$ & $1 \pm 0.8$ & $2 \pm 1.3$ & $3 \pm 3.2$ & $3 \pm 2.8$ \\
\hline Eragrostis spp. & $5 \pm 2.1$ & $6 \pm 2.7$ & $1 \pm 2.1$ & $<1 \pm 0.5$ & $3 \pm 1.9$ & $<1 \pm 0.3$ & $<1 \pm 0.6$ & $3 \pm 2.1$ & $2 \pm 1.5$ & $<1 \pm 0.8$ \\
\hline Aristida spp. & $1 \pm 1.8$ & $5 \pm 3.0$ & $<1 \pm 0.7$ & $1 \pm 1.6$ & $2 \pm 2.2$ & $<1 \pm 0.8$ & $4 \pm 2.6$ & $1 \pm 0.8$ & $<1 \pm 0.2$ & $<1 \pm 0.2$ \\
\hline Sporobolus cryptandrus & - & $<1 \pm 0.9$ & $1 \pm 0.8$ & $1 \pm 1.2$ & $1 \pm 0.8$ & $2 \pm 1.0$ & $2 \pm 1.9$ & $2 \pm 2.1$ & $<1 \pm 0.2$ & $4 \pm 1.4$ \\
\hline Setaria leucopila & $2 \pm 2.7$ & $<1 \pm 0.8$ & - & - & $<1 \pm 0.2$ & $<1 \pm 0.2$ & $<\mathrm{I} \pm 0.5$ & - & $<1 \pm 0.6$ & $<1 \pm 0.2$ \\
\hline saccharoides & $<1 \pm 0.9$ & $<1 \pm 0.3$ & $<1 \pm 0.2$ & $<1 \pm 0.5$ & $2 \pm 0.8$ & - & - & $<1 \pm 0.3$ & $<1 \pm 0.2$ & $<1 \pm 0.2$ \\
\hline Stipa leucotricha & - & - & - & $<1 \pm 0.3$ & - & $<1 \pm 0.2$ & - & $<1 \pm 0.3$ & - & $<1 \pm 0.2$ \\
\hline Unknown grasses & $<1 \pm 0.2$ & $<1 \pm 0.4$ & - & $2 \pm 0.9$ & $<1 \pm 0.4$ & $<1 \pm 0.2$ & $<1 \pm 0.2$ & $<1 \pm 0.3$ & $<1 \pm 0.5$ & $<1 \pm 0.3$ \\
\hline Total grasses & $92 \pm 2.5$ & $90 \pm 2.4$ & $87 \pm 2.4$ & $65 \pm 2.2$ & $76 \pm 2.1$ & $26 \pm 0.8$ & $37 \pm 1.1$ & $46 \pm 1.2$ & $34 \pm 0.9$ & $42 \pm 2.1$ \\
\hline \multicolumn{11}{|l|}{ Forbs } \\
\hline Sphaeralcea spp. & - & - & - & - & - & $51 \pm 4.9$ & $35 \pm 7.0$ & $22 \pm 8.2$ & $14 \pm 3.2$ & $6 \pm 1.3$ \\
\hline Sida filicaulis & $6 \pm 1.2$ & $8 \pm 4.0$ & $7 \pm 1.4$ & $13 \pm 5.2$ & $10 \pm 0.5$ & $6 \pm 0.5$ & $10 \pm 2.8$ & $3 \pm 0.2$ & $6 \pm 2.8$ & $14 \pm 3.7$ \\
\hline Lesquerella gracilis & - & - & - & - & - & $5 \pm 1.5$ & $6 \pm 0.9$ & $5 \pm 2.5$ & $11 \pm 5.3$ & $19 \pm 12.4$ \\
\hline Abutilon incanum & - & - & - & - & - & $7 \pm 1.7$ & $5 \pm 2.8$ & $2 \pm 1.4$ & $<1 \pm 0.7$ & - \\
\hline Solanum rostratum & - & - & - & - & - & $4 \pm 2.0$ & $5 \pm 0.7$ & $2 \pm 0.8$ & $<1 \pm 0.4$ & $3 \pm 2.6$ \\
\hline Erodium texanum & - & - & - & - & - & - & $1 \pm 0.7$ & $2 \pm 0.7$ & $<1 \pm 0.6$ & - \\
\hline Dyssodia acerosa & - & - & - & - & - & - & - & $3 \pm 0.9$ & - & - \\
\hline Plantago rhodosperma & - & - & - & - & - & - & $<1 \pm 0.2$ & - & $<1 \pm 0.7$ & $<1 \pm 0.2$ \\
\hline Zinnia anomala & 一 & - & - & - & - & - & - & - & - & $<1 \pm 0.2$ \\
\hline Coldenia canescens & - & - & - & - & - & - & - & - & - & $<1 \pm 0.2$ \\
\hline $\begin{array}{l}\text { Unknown forbs } \\
\text { Total forbs }\end{array}$ & $\begin{array}{r}<1 \pm 0.5 \\
7 \pm 1.9\end{array}$ & $\begin{array}{l}1 \pm 0.8 \\
9 \pm 3.0\end{array}$ & $\begin{array}{l}2 \pm 0.6 \\
9 \pm 2.0\end{array}$ & $\begin{array}{r}1 \pm 1.1 \\
14 \pm 4.6\end{array}$ & $\begin{array}{l}<1 \pm 1.1 \\
10 \pm 2.3\end{array}$ & $\begin{array}{l}<1 \pm 0.2 \\
73 \pm 6.5\end{array}$ & $\begin{array}{l}<1 \pm 0.4 \\
62 \pm 3.6\end{array}$ & $\begin{array}{r}1 \pm 0.8 \\
40 \pm 2.3\end{array}$ & $\begin{array}{l}<1 \pm 0.4 \\
32 \pm 1.8\end{array}$ & $42 \pm 3.4$ \\
\hline \multicolumn{11}{|l|}{ Browse } \\
\hline Rhus microphylla & $<1 \pm 0.3$ & - & $3 \pm 2.8$ & $18 \pm 3.6$ & $11 \pm 1.5$ & $<1 \pm 0.2$ & - & $6 \pm 3.5$ & $13 \pm 3.7$ & $12 \pm 4.7$ \\
\hline Lycium texanum & - & - & - & - & - & - & - & $6 \pm 2.0$ & $10 \pm 4.0$ & - \\
\hline Juniperus pinchotii & - & - & - & $\ldots$ & $1 \pm 0.5$ & - & 一 & - & $5 \pm 1.9$ & $3 \pm 3.1$ \\
\hline Microrhamnus ericoides & - & $<1 \pm 0.3$ & $<1 \pm 0.3$ & $2 \pm 1.5$ & $<1 \pm 0.6$ & - & - & - & $4 \pm 2.6$ & $<1 \pm 0.3$ \\
\hline Prosopis glandulosa & - & - & $<1 \pm 0.3$ & $1 \pm 0.3$ & - & $<1 \pm 0.2$ & $<1 \pm 0.3$ & - & - & - \\
\hline Bernardia obovata & 一 & - & - & - & - & - & - & $1 \pm 1.2$ & $2 \pm 2.1$ & - \\
\hline Flourensia cernua & - & - & - & - & - & - & - & $<1 \pm 0.2$ & - & - \\
\hline Larrea tridentata & - & - & $<1 \pm 0.5$ & - & - & - & - & - & - & - \\
\hline Dalea formosa & - & - & - & - & - & - & - & - & - & $<1 \pm 0.3$ \\
\hline Total browse & $<1 \pm 0.3$ & $<1 \pm 0.3$ & $4 \pm 0.7$ & $20 \pm 4.5$ & $13 \pm 2.9$ & $<1 \pm 0.1$ & $<1 \pm 0.3$ & $14 \pm 1.6$ & $34 \pm 1.9$ & $16 \pm 2.2$ \\
\hline
\end{tabular}


Table 7. Mean ( $\pm 2 S E)$ standing crop of herbage $(\mathrm{kg} / \mathrm{ha})$ in a creosotebush-tarbush community in Pecos County, Texas.

\begin{tabular}{lc}
\hline \hline Forage species & $\begin{array}{c}\text { September } 1980 \\
(\mathrm{~kg} / \mathrm{ha})\end{array}$ \\
\hline Grasses & \\
Scleropogon brevifolius & $846 \pm 215$ \\
Aristida spp. & $67 \pm 67$ \\
Sporobolus cryptandrus & $29 \pm 58$ \\
Setaria leucopila & $26 \pm 48$ \\
Hilaria mutica & $21 \pm 42$ \\
Muhlenbergia spp. & $12 \pm 25$ \\
Total grasses & 1,001 \\
& \\
Forbs & $35 \pm 49$ \\
Croton dioicus & $32 \pm 64$ \\
Salvia reflexa & $32 \pm 32$ \\
Dyssodia acerosa & $27 \pm 53$ \\
Sida filicaulis & $11 \pm 81$ \\
Acleisanthes longiflora & 137 \\
Total forbs & \\
Browse & $257 \pm 82$ \\
Larrea tridentata & $104 \pm 6$ \\
Flourensia cernua & $33 \pm 12$ \\
Dalea formosa & $10 \pm 19$ \\
Microrhamnus ericoides & 404 \\
Total browse & \\
\hline
\end{tabular}

\section{Conclusions}

Barbado sheep generally utilized more browse and less grass than Rambouillet or Karakul sheep, thereby occupying a food niche intermediate between the other sheep and goat breeds studied. In 2 cases, Barbado sheep and Angora goats consumed browse and forbs in similar proportions. The goat breeds, mainly Spanish goats, consistently utilized browse as staple foods, especially in pastures or seasons where forbs were not plentiful. Spanish goats exhibited the greatest tendency to utilize browse, even when availability appeared low due to an elevated browse line. Barbado sheep tended to consume more undesirable brush species, specifically lotebush, juniper, and catclaw acacia, than other sheep breeds. However, the major undesirable brush species on the study areas, including honey mesquite, creosotebush, tarbush, juniper, lotebush, catclaw acacia, and algerita, were not consumed in appreciable quantities by any of the sheep or goat breeds studied: Karakul sheep could apparently be substituted for Rambouillet sheep in most range types with little effect on the plant resource;
Table 9. Mean similarity indices of diets of various breeds of sheep and goats grazing in three plant communities in west Texas, 1979-1981.

\begin{tabular}{lcccc}
\hline \hline & \multicolumn{4}{c}{ Tom } \\
Breed relationship & $\begin{array}{c}\text { Edwards } \\
\text { County }\end{array}$ & $\begin{array}{c}\text { Green } \\
\text { County }\end{array}$ & $\begin{array}{c}\text { Pecos } \\
\text { County }\end{array}$ & Means \\
\hline Spanish vs. Angora & 57 & 75 & 71 & 69 \\
Spanish vs. Barbado & 46 & 58 & 62 & 55 \\
Spanish vs. Karakul & 41 & 61 & 62 & 55 \\
Spanish vs. Rambouillet & 41 & 46 & 51 & 46 \\
Angora vs. Barbado & 66 & 81 & 62 & 70 \\
Angora vs. Karakul & 64 & 57 & 67 & 63 \\
Angora vs. Rambouillet & 65 & 54 & 53 & 57 \\
Barbado vs. Karakul & 81 & 78 & 68 & 76 \\
Barbado vs. Rambouillet & 76 & 74 & 65 & 72 \\
Karakul vs. Rambouillet & 85 & 83 & 76 & 81 \\
\hline
\end{tabular}

however, they offer no advantage over Rambouillet sheep for suppressing undesirable shrubs.

\section{Literature Cited}

Anthony, R.B., and N.S. Smith. 1974. Comparison of rumen and fecal analysis to describe deer diets. J. Wildl. Manage. 38:535-540.

Arnold, G.W. 1960. Selective grazing by sheep of two forage species at different stages of growth. Aust. J. Agr. Res. 11:1026-1033.

Bryant, F.C., M.M. Kothmann, and L.B. Merrill. 1979. Diets of sheep, Angora goats, Spanish goats, and white-tailed deer under excellent range conditions. J. Range Manage. 32:412-417.

Campibeil, Q.O., J.F. Ebersòin, añd L.H. voun Broembsen. 196́2. Browsing by goats and its effect on the vegetation. Herb. Abstr. 32:273-275.

Dudzinski, M.L., and G.W. Arnold. 1973. Comparisons of diets of sheep and cattle grazing together on sown pastures on the southern tablelands of New South Wales by principal components analysis. Aust. J. Agr. Res. 24:899-912.

Ellis, B.A., E.M. Russell, T.J. Dawson, and C.J.F. Harrop. 1977.Seasonal changes in diet preferences of free-ranging red kangaroos, euros and sheep in western New South Wales. Aust. J. Agr. Res. 4:127=144.

Hamilton, B.A., K.J. Hutchinson, P.C. Annis, and J.B. Connelley. 1973. Relationships between the diet selected by grazing sheep and herbage on offer. Aust. J. Agr. Res. 24:271-277.

Holechek, J.L., M. Vavra, and R.D. Pieper. 1982. Botanical composition determination of range herbivore diets: A review. J. Range Manage. 35:309-315.

MacCracken, J.G., and R.M. Hansen. 1981. Diets of domestic sheep and other large herbivores in south central Colorado. J. Range Manage. 34:242-243.

Maher, C. 1945. The goat: Friend or foe? East Afr. Agr. J. 11:115-121.

Malechek, J.C., and C.L. Lêinweber. 1972. Forage selectivity by goats on lightly and heavily grazed ranges. J. Range Manage. 25:105-111.

Table 10. Spearman rank order correlation coefficients of diets of five breeds of sheep and goats with food availability in three different plant communities in western Texas. ${ }^{1}$

\begin{tabular}{|c|c|c|c|c|c|c|c|c|c|}
\hline \multirow{3}{*}{$\frac{\text { Breeds }}{\text { Rambouillet sheep }}$} & \multicolumn{2}{|c|}{ Edwards County } & \multicolumn{4}{|c|}{ Tom Green County } & \multicolumn{2}{|c|}{ Pecos County } & \multirow[b]{2}{*}{ Means } \\
\hline & \multicolumn{2}{|c|}{ Nov. 1979/Feb. 1980} & \multicolumn{2}{|c|}{ May 1980/Aug. 1980} & \multicolumn{2}{|c|}{ Feb. 1981/Apr. 1981} & \multicolumn{2}{|c|}{ Sept. $1980 /$ Nov. 1980} & \\
\hline & $\begin{array}{c}0.44 \\
(0.05)\end{array}$ & $\begin{array}{c}0.41 \\
(0.11)\end{array}$ & $\begin{array}{c}0.03 \\
(0.37)\end{array}$ & $\begin{array}{c}0.40 \\
(0.10)\end{array}$ & $\begin{array}{c}0.50 \\
(0.02)\end{array}$ & $\begin{array}{c}0.11 \\
(0.53)\end{array}$ & $\begin{array}{c}0.13 \\
(0.60)\end{array}$ & $\begin{array}{c}0.04 \\
(0.82)\end{array}$ & 0.22 \\
\hline Karakul sheep & $\begin{array}{c}0.37 \\
(0.10)\end{array}$ & $\begin{array}{c}0.47 \\
(0.06)\end{array}$ & $\begin{array}{c}0.37 \\
(0.14)\end{array}$ & $\begin{array}{c}0.47 \\
(0.02)\end{array}$ & $\begin{array}{c}0.56 \\
(0.01)\end{array}$ & $\begin{array}{c}0.06 \\
(0.73)\end{array}$ & $\begin{array}{c}0.17 \\
(0.50)\end{array}$ & $\begin{array}{c}0.00 \\
(0.99)\end{array}$ & 0.31 \\
\hline Barbado sheep & $\begin{array}{c}0.21 \\
(0.36)\end{array}$ & $\begin{array}{c}0.31 \\
(0.22)\end{array}$ & $\begin{array}{c}0.10 \\
(0.71)\end{array}$ & $\begin{array}{c}0.56 \\
(0.02)\end{array}$ & $\begin{array}{c}0.48 \\
(0.03)\end{array}$ & $\begin{array}{c}0.15 \\
(0.38)\end{array}$ & $\begin{array}{c}0.03 \\
(0.91)\end{array}$ & $\begin{array}{l}-0.05 \\
(0.78)\end{array}$ & 0.22 \\
\hline Spanish goats & $\begin{array}{c}0.30 \\
(0.19)\end{array}$ & $\begin{array}{c}0.19 \\
(0.47)\end{array}$ & $\begin{array}{c}0.14 \\
(0.61)\end{array}$ & $\begin{array}{r}0.10 \\
(0.69)\end{array}$ & $\begin{array}{c}0.26 \\
(0.25)\end{array}$ & $\begin{array}{c}0.16 \\
(0.36)\end{array}$ & $\begin{array}{l}-0.04 \\
(0.89)\end{array}$ & $\begin{array}{l}-0.13 \\
(0.51)\end{array}$ & 0.12 \\
\hline Angora goats & $\begin{array}{c}0.38 \\
(0.09)\end{array}$ & $\begin{array}{c}0.23 \\
(0.37)\end{array}$ & $\begin{array}{l}-0.13 \\
(0.63)\end{array}$ & $\begin{array}{c}0.17 \\
(0.50)\end{array}$ & $\begin{array}{c}0.36 \\
(0.11)\end{array}$ & $\begin{array}{c}0.16 \\
(0.36)\end{array}$ & $\begin{array}{l}-0.07 \\
(0.79)\end{array}$ & $\begin{array}{l}-0.01 \\
(0.94)\end{array}$ & 0.14 \\
\hline Means & 0.39 & 0.32 & 0.10 & 0.34 & 0.34 & 0.13 & -0.01 & -0.05 & \\
\hline
\end{tabular}

IValues in parentheses beneath each correlation coefficient indicate probability of significance. 
Merrill, L.B. 1975. The role of goats in biological control of brush. p. 372-376. In: Beef Cattle Science Handbook Vol. 12. International Stockmen's School, San Antonio, Texas.

Merrill, L.B., and C.A. Taylor. 1976. Take note of the versatile goat. Rangeman's J. 3:74-76.

Meyer, J.H., G.P. Lofgreen, and J.L. Hull. 1957. Selective grazing by sheep and cattle. J. Anim. Sei. 16:766-772.

Oosting, H.J. 1956. The study of plant communities. W.H. Freeman \& Co. San Francisco.

Polochek, V. 1980. Soil Conservationist with U.S. Dep. of Agr. Soil Conservation Serv. Sonora, Texas.

Rives, J.L. 1980. Soil survey of Pecos County, Texas. U.S. Dep. Agr., Soil Conser. Service.

Scifres, C.J. 1980. Brush management; principles and practices for Texas and the Southwest. Texas A\&M University Press, College Station.

Snedecor, G.W., and W.G. Cochran. 1973. Statistical methods. Iowa State Univ. Press, Ames.

Sparks, D.R., and J.C. Malechek. 1968. Estimating percentage dry weight in diets using a microscopic technique. J. Range Manage. 21:264-265.

Staples, R.R., H.E. Hornby, and R.M. Hornby. 1942. A study of the comparative effects of goats and cattle on a mixed grass-brush pasture. East Afr. Agr. J. 8:62-70.
Van Dyne, G.M. 1968. Measuring quantity and quality of the diet of large herbivores. p. 54 In: F.B. Golley and H.K. Buchner (eds). A practical guide to the study of the productivity of large herbivores. Int. Biol. Programme Handb. 7. Blackwell Scientific Publications. Oxford and Edinburg.

Van Dyne, G.M., and H.R. Heady. 1965. Botanical composition of sheep and cattle diets on a mature annual range. Hilgardia 36:465-492.

Vavra, M., R.W. Rice, and R.M. Hansen. 1978. A comparison of esophageal fistula and fecal material to determine steer diets. J. Range Manage. 31:11-13.

Weidenfeld, C.C., and P.H. Flores. 1976. Soil survey of Tom Green County, Texas. U.S. Dep. Agr., Soil Conser. Service.

Westoby, M., G.R. Rost, and J.A. Weis. 1976. Problems with estimating herbivore diets by microscopically identifying plant fragments from stomachs. J. Mammal. 57:167-172.

Wilson, A.D. 1976. Comparison of sheep and cattle grazing on semiarid grassland. Aust. J. Agr. Res. 27:155-162.

Wilson, A.D., J.H. Leigh, N.L. Hindley, and W.E. Mulhan. 1975. Comparison of the diets of goats and sheep on a Casuarins cristatta-Heterodendrum oleifolium woodland community in western New South Wales. Aust. J. Exp. Agr. and Anim. Husb. 15:45-53. 